\title{
Why Private Sector Led Financial Inclusion Cannot Work for Development? Case of Micro Credit in India
}

\author{
Seema Sahai \\ Research Fellow \\ Public Policy, Management Development Institute, Gurgaon, India \\ E-mail: seemassahai@gmail.com \\ Rupamanjari Sinha Ray \\ Assistant Professor \\ Economics Area, Management Development Institute, Gurgaon, India \\ E-mail: rupamanjari@mdi.ac.in \\ S K Tapasvi \\ Professor \\ Public Policy, Management Development Institute, Gurgaon, India \\ E-mail: tapasvi@mdi.ac.in
}

\begin{abstract}
This paper analyzes the potential of the private sector-led micro-credit business to impact poverty. Despite the financial and policy support by donor agencies and multilateral agencies microcredit has not been able to create a positive impact on household income. The study concludes that the credit policy of private sector providers is not designed to create a substantial impact. Microcredit is a business model for doing business with the poor. All aspects of a credit policy including selection criteria, appraisal process, and product offered, and loan amount serves the interest of the lender and not that of the client.
\end{abstract}

Keywords: Microfinance, Financial Inclusion, Impact of Microfinance, Microenterprises.

\section{Introduction}

There has been a paradigm shift towards outsourcing development by involving private players in resolving development issues-particularly in developing countries. Governments across the globe and multilateral agencies are increasingly practicing this policy shift. The premise is that it will bring better results due to the efficiency and availability of funds. This paper is an attempt to examine this policy shift by examining the policy of financial inclusion through private Micro Finance Companies (MFI) in India.

\section{The Innovation Called Microfinance}

The premise underlying the concept of microcredit- as conceptualized by Mohammad Yunus, is that poor lack capital and microcredit would help them invest in productive activity, enhance household income and resultantly reduce poverty. This simplistic solution to the complex problem of poverty has evoked overwhelming support for microcredit from policy quarters including governments across the globe, the United Nations, World Bank, and donor agencies.

Mohammad Yunus conceptualized the microcredit model to make the poor bankable- that is- the loan lent to the poor is repaid. Improvising the gaps in the existing banking system an innovative business model for lending to the poor in a sustainable way was developed. No principles of prudent banking were compromised--only their format was changed. Thus, physical collateral was replaced by social collateral- wherein group members stood guarantee for each other; weekly repayment schedule replaced monthly repayments to match the cash flow of poor; doorstep banking was offered. These changes made borrowing easy for the poor. For the lender, this business model ensured repayments and a reasonable margin to cover the high transaction cost of small ticket size of loans. The rate of interest charged by the Microcredit providers was lower than the private sources like money -lenders. The hence higher interest rate was acceptable and even welcome by borrowers and policymakers. This easy availability of credit for poor facing constant cash crunch at the bottom of the pyramid on the one hand and a profitable business opportunity for the lender on the other made microfinance truly a winwin proposition as termed by Prahlad (2004). Thus, microcredit is truly a market- based solution to financial inclusion. UN has also approved and promoted the private sector-led poverty reduction initiatives in financial inclusion. Since the original intention for developing a micro-credit business model was to help the poor move out of the poverty cycle by 
providing them credit support that philanthropic image continues to be associated with microcredit. This image helped MFIs to attract funds and policy support from donor agencies and multilateral agencies in the hope of helping poverty eradication. But the studies carried out to assess the impact of microcredit has a different story to tell.

\section{I. Impact of Micro Credit on the Beneficiaries}

Most recently six experimental studies or the Random Control Trials (RCTs) carried out in different parts of the globe concluded that the impact of microfinance is at best modestly positive and not transformative (Banerjee et al., 20I4). Even that modestly positive impact varies amongst the clients with as high as $25 \%$ of clients reporting even negative profits (Crepon, 201I). These studies are conducted in six different countries (Ethiopia, India, Mexico, Mongolia, Bosnia, and Morocco); conducted on both urban and rural population; used Experimental methods (RCTs) to minimize the methodological weaknesses like self-selection bias and choice of control group; and have done both individual-level and area-level randomization to take into account the spillover impact. Despite these variations, the conclusions are the same that there is no transformative impact. These RCTs have put a stamp of confirmation on findings of earlier studies (Yunus, 1998; Sinha, 2007). There is no conclusive proof of the positive impact of microcredit (Duvendack et al., 20II; Chowdhury, 2009).

\subsection{Impact on the Micro Credit Providers}

On the other hand, the microfinance industry has shown tremendous growth in terms of the number of clients and the amount of loan disbursed. The global microfinance sector is expected to grow by $15-20 \%$ in the year 2015 . A growth rate of $44 \%$ in the credit amount and $23 \%$ in client base was registered in the first quarter of FY 20I5- I6 against the same period in FY20I4-I5 as per microfinance Industry association in India 'MFIN'. The reason for this incongruence in the growth of microfinance providers and that on the clients is obvious. Microcredit offered a new business model for the lender and not for the poor. Sustainability of the lender and not that of the poor was ensured. For the poor, the model just assumed that the poor lack capital and credit would help them find the way out of poverty.

This leads us to question two basic premises put forward by the microcredit model- one-whether credit as a development intervention help poor enhance their income, and second, the private sector-led intervention for financial inclusion. Many studies have recognized the limited role of credit (Nichter \& Goldmark, 2009; Kuzilwa, 2005; Chowdhury, 2009). This paper analyzes the second premise underlying the microcredit model- that market- based solutions can help achieve the goal of poverty eradication If there is a tremendous growth of lender and no growth of borrower then we need to question whether this incongruence has its genesis in the microcredit business model itself. The model focuses on the sustainability of the lender. The sustainability comes from a reasonable profit allowed in the model. This further leads us to question whether this profit motive and commercial interest are the reason for the lack of impact? This premise is the basis for policy support for microcredit. Many scholars (Bateman \& Chang, 2008) have questioned the microcredit model on this ground. To analyze this premise, we arrive at the research question: Is there incongruence between the commercial interest of the MFIs and the impact on the household poverty level?

In India, 96\% of total microcredit borrowers are covered by 'for profit' Micro Finance Institutions (MFIs) (MCRIL, 20I4)- another confirmation of dominance of commercial interest of lenders. To put things in perspective it is pertinent to point out that MFIs are just lenders. Since the role of credit as a development initiative is limited as mentioned above so it is unfair to hold MFIs solely responsible for the overall lack of impact. MFIs are lenders; so it is fair to analyze the credit policies pursued by the MFIs to understand whether the credit policies can meet the capital requirements of the poor for carrying out the productive activity. Cohen (2002); Meyer (200I) have analyzed the credit policies to enable the MFIs to sustain themselves because of increased competition. This study aims to analyze the credit policy to understand whether the sustainability and commercial interest of the lender is compatible with the objective of adequate credit support to the productive activity of the poor to come out of the poverty cycle.

The microfinance model proposes the loan has to be for productive purposes. In India government has stipulations that $85 \%$ of credits by MFIs must go for productive loans. In the paper, we look at the possible support that credit can give to the productive activity of the poor. Poor carry out these productive activities through their microenterprises. Micro enterprises are most aptly defined as the enterprise of poor (ADB, 1997).

The objective of the study was to analyze the credit policy of MFIs in terms of their client focus and potential to fill the capital gap faced by the poor in starting and running their micro-enterprises.

\section{Methodology}

This study analyzed the credit policies of three Microfinance Institutions. All three microcredit providers were 'for profit' Non-Banking Financial Companies (NBFC). We name these as MFI I, MFI 2, and MFI 3.

The credit policy shared by management was analyzed. Borrowers of each MFI were interviewed to understand their experience and perspective. FGDs and personal interviews of clients were done. Application forms, appraisal forms, and MFI branch office records were perused. Content analysis of data was done. The area of operation of MFI I was the State of Rajasthan in India and the area of operation of MFI2 and MFI 3 was the State of Uttar Pradesh in India. 
Credit policy was to be analyzed in its potential to create an impact on Micro Enterprises. The impact was measured through the growth of Microenterprises. Indicator of growth was employment generation- a well-accepted indicator of growth in existing literature (Nichter \& Goldmark, 2009).

\section{Findings}

The evidence strongly proved that microcredit policies are not designed to create an impact for the micro-enterprises supported by them.

All three MFIs had exactly similar lending policies except for the loan amount, which varied marginally between INRI2000- to INRI5000. Borrowers were associated with the MFI for a minimum of 2 years in all cases.

Credit provided by MFIs is an important source of credit for the borrowers. It is a cheap and hassle-free, easily available loan as compared to any other source of loans. This loan was timely available. All clients had clear calculations about the comparative cost of different sources of funds like private lenders and MFIs. Borrowers found this loan cheaper as compared to other sources of funds. Even if microcredit was not available due to a shortage of funds in MFI (as was the case in MFI I at the time of the study) the clients were ready to wait for it rather than going to private money- lenders. Not only was this loan cheap it was also easily available at the doorstep saving the borrowers the problem of running around for a loan. The loans offered by Government banks were much cheaper but borrowers didn't go to government banks. The opportunity cost was of approaching Government banks was high because it resulted in wastage of productive time. In Government Bank systems were complex and the bank staff was non-cooperative. Against this, MFI loan officers visited the clients at the doorstep and were responsive and cooperative. Loan executives in the field have good relations with the borrowers.

Moreover, the loan is considered as fair, transparent and honest. Clients were confident that if they fulfill the criteria then they should get a loan without any hassles.

In absence of any other credible alternative source of the loan, MFI loans are welcome- a fact confirming the observations by Cohen (2002). Despite this, we find that growth (employment generation) could not be attributed to credit. The policies are top-down and true to the observations by Cohen (2002) are not in alignment with the business needs and heterogeneity of the micro-enterprises. The growth-oriented enterprises already had employees or full-time employment for family members before they opted for the loan. There was not a single case out of 205 respondents where growth could be attributed to microcredit. All enterprises, which showed growth, had done so before getting the loan.

The main reasons for this lack of growth are as follows in the next section. The lending policy is and guided by the business interests of the MFI rather than the business interests of the micro-enterprises as reflected in the following aspects of credit policy.

\section{I Eligibility Criteria of a Borrower}

The eligibility criteria of all the MFIs included:

- The enterprise should have existed for at least a year.

- The household must own a Pakka (Brick and cement) house,

- The client must be a permanent resident of the area.

All the clients fulfilled these criteria. These pre-conditions for client selection are prudent lending norms and ensure repayments but these selection criteria could not create a transformative impact.

Firstly, the impact of credit can be transformative only if a productive asset is created. But as per the eligibility criteria, the investment in the productive asset was already done. So transformative change if any could not be attributed to credit. Further, the condition requires that the enterprise has not only made that investment but it has sustained for a year. The micro-enterprises are vulnerable enterprises with thin margins. The enterprise that has made an investment in start-up and survived a year has already crossed the most vulnerable period when it needed the capital support the most. In such cases, capital support comes from own resources. Only those who already had capital could survive. Crepon et al., (20II) have also noted in their study on the Al Amana program in Morocco that financing is done only for existing activities with a track record. This also leaves the theoretical client of microcredit who needs credit for productive assets out of the scope.

Next, the condition of a household with a Pakka house categorically leaves the very poor out. Sinha (2007) has concluded based on a study of the top 20 MFIs in India that approximately $35 \%$ of clients are not even poor. So, it is not logical to expect a dent in poverty with this credit policy.

Further, these selection criteria make the choice of eligible borrowers very limited. All MFIs target the same set of borrowers. This fact has been confirmed in many studies. A study by M- CRIL, 2012 has found that as many as $40 \%$ of the client- base of the microfinance sector in India as in March 201 I is due to overlapping of clients. This phenomenon of 'SHG poaching' (instead of finding new clients MFIs lend to the trusted members of existing SHGs developed for government lending programs) has been one of the major reasons for multi borrowing and over-indebtedness of poor clients. This practice and resultant heavy indebtedness has been noted in studies and also by the government. This practice, on the one hand, makes the eligible client vulnerable and on the other hand, leaves the poor client outside the scope of MFI business policy. That was the reason that the Reserve bank of India limited the number of loan accounts of borrowers to two. 
Thus, we found that due to the selection criteria of MFIs the impact is bound to be low or negligible. Firstly, because it selects only preexisting units, which have already invested in the productive asset. Secondly, the very poor client is out of the scope of a 'for profit' MFI.

\subsection{Loan Appraisal System}

The MFIs appraisal process does not take into account the enterprise business needs. A perusal of the forms showed that the loan appraisal forms does not have columns for assessing the enterprise business needs like working capital gap, gestation period, or expected cash flow of the business or even the scope of the activity. Rather it has columns for assessing present repayment capacity of the clients like present household income, number of earning members, number of vehicles, etc. The present repayment capacity rather than future expected cash flow is the criterion for appraisal of the client. For instance, if a client can afford to send children to English schools (English Medium schools which are costlier than vernacular medium schools) and the household owns a two-wheeler, she/ he is more likely to repay the loan. Since the payment does not come from the enterprise income enterprise growth is not the concern of the MFI.

The loan is given for existing units hence obviously there is no appraisal for the fixed asset requirement of the enterprise. But more importantly, the appraisal system does not have provisions to consider even the working capital gap for an already running enterprise. Based on the analysis of application and appraisal form, and field-level appraisal processes the study finds that the appraisal system is more of an exercise in baseline data collection about the household, and checking the references and antecedents. This simplifies the appraisal system and decision-making. This facilitates scaling up but this system eventually leads the impact to be limited to consumption smoothening. Thus the guiding principle for loan appraisals is to support the MFI business interest and not the business interest of the micro-enterprises.

\subsection{Single Loan Product}

Thirdly, there is a single loan product on offer while enterprise needs vary significantly. The MFI product list might have more products but for all practical purposes, all MFIs have only one product to offer for a particular area. There is no flexibility and the credit product offered has a similar loan amount, repayable in a similar repayment period, with similar installment amount, and similar terms and conditions for all the borrowers in all three MFIs. The heterogeneous needs of the enterprises are not taken into account while designing the product. For example, the respondents interviewed had different occupations- photocopier, a tailor, a beauty parlor, and a welder- to name a few. These occupations have a huge difference in investment needs- a photocopying machine costs above INR 100,000 and a sewing machine costs under INR 5000 but all were given similar loan amounts of INR I5000.

Even repayment programs have no flexibility to accommodate the gestation period of activity. For example, a retail shop may not require any gestation period but a manufacturing enterprise or an artisan may require different gestation periods. Since the repayments start immediately first few installments are paid from the loan amount itself. This further reduces the loan amount available for investment.

Similarly, the growth potential of different enterprises is not considered. An already established enterprise catering to a value chain like potato storage or Zardozi embroidery has a higher scope of growth as compared to an enterprise, which is doing a home-based activity and catering to neighborhood demand like home-based Kirana shop. A product designed to cater to the credit needs of enterprises with more scope may lead to higher employment generation while the lack of a wellsuited product may hamper the growth prospects. But the assessment of the growth potential of the enterprises is beyond the scope of the MFIs. These single products are easy to administer because the loan officer collects similar installments from all the borrowers, calculation of EMIs are easy, and defaults are easy to detect. This leads to lower staff requirements for the MFI.

Thus, the focus of MFIs is on homogeneity for easy administration of loans and not the enterprise needs. This policy can do well for cost optimization for the lender but cannot bring about a transformative change for the enterprise. Meyer (2002) has rightly pointed out that "The one-year working capital group loan made to poor women with weekly installments and little or no grace period is the bread and butter product for most Bangladeshi MFIs. The advantage of this product is that it is easy for clients to understand, for loan officers to manage, and for MFIs to maintain internal control with manual bookkeeping systems". Thus, the policy is guided by the profit considerations of MFI and not the growth of the enterprise.

A few studies have focused on the impact of flexible repayment period on enterprise performance. These studies find, given a grace period, enterprises can show higher returns as they get the opportunity to invest in illiquid assets (Field et al., 2013). In our study, however, we find that there is no scope for such a decision, as the investment decision is not taken based on the loan. This is a policy common to all the MFIs indicating that a single uniform product is a rule and not an exception. Besides other studies like Cohen (2002); Meyer (200I) has also noted similar observations. This policy again does not have the potential to bring about any substantial change in household income.

\subsection{Inadequacy of Loan Amount}

Fourthly even this single product offers an inadequate amount of loan. Under financing is not a good lending practice as it throttles the growth prospects and leads to further indebtedness. All the entrepreneurs found the loan amount inadequate. It was inadequate to create even average income-generating investment. For example, while a buffalo costs more than Rs 
40,000 the loan amount was just Rs I2000- I5000. There were cases that those who could not manage the balance amount bought a calf instead. By the admission of MFI field staff, the amount offered was not sufficient to start a new profitgenerating enterprise. Adam \& Bartholomew (2010) in a study of the impact of microfinance in Ghana has also mentioned a small loan amount as a reason for the inability of the borrower to repay the loan amount. Since the loan amount is inadequate for productive asset creation, and the enterprise has already created the asset, the loan was used mostly as working capital. It was used to replenish the stock in case of traders or raw material in the case of manufacturers or consumables in the case of enterprises like mechanic and motor winders. The role of working capital cannot be undermined for any enterprise hence this loan could help the enterprises as a source of working capital. But the loan amount was inadequate even as working capital

Enterprises that are part of value chains have constant demand and a higher loan amount can help them grow and generate more employment. These clients wanted higher amounts and were ready to repay a higher amount on the same terms and conditions. Similarly, enterprises carrying out high investment work like furniture making were ready to repay 5-6 times higher loan amount within the same repayment period because a higher loan amount would give them leverage to earn in peak period and prepare for the next season in advance. These enterprises are high investment businesses and cannot do with a small loan amount. The loan amount is insufficient to meet the peak season demand even for general merchant shops that have to stock for festival seasons. The capital crunch was mentioned as the single most important reason by the enterprises as a reason for laggard growth.

Multiple borrowing from another MFI was availed by all growth-oriented enterprises and survivalist enterprises wherever it was available. With the constant need for funds and limited loan amount and with all MFIs offering a loan with similar terms multiple borrowing was a convenient option. Meyer (200I) has mentioned the same reason for multiple borrowings in the context of Bangladesh MFIs. This inadequacy also leads to borrowing from expensive private sources, which further erodes the already thin margin. The inadequacy of the loan is again strong evidence of the credit policy being indifferent to client needs. Such a policy cannot bring about substantial change.

\subsection{Fungibility of the Loan amount}

The study finds that in all the enterprises- whether growth-oriented enterprises or survivalist enterprises the loan amount constituted a small part of total investment in the enterprise. The loan amount was part of the household corpus of funds and was rotated and used as per household priorities.

Cohen (2002) has also pointed out that since clients do not have any control over the product, they adjust their needs according to the loan amount. This applies to both growth-oriented enterprises and survivalist enterprises but more to the growth-oriented enterprises. In this study, we find that diversion of the loan amount was found more in households with higher income. The entrepreneurs that have no other source of capital were more likely to use the loan amount in the enterprise. Growth-oriented enterprises or those who had multiple sources of income used the loan amount for other activities like purchase of motorcycle, or spouse's business or marriage in the household. Thus, clearly fungibility is not the reason for lack of impact.

This fact was in knowledge of MFI officials also but since it did not impact the repayment performance there was no reason to check the practice. The loan amount was small and it could not impact productivity anyway. We find that fungibility does not impact repayments. This finding truly reflected the observation by Dichter (2007) that money is fungible and can be used for anything and the poor use it to iron out the highs and lows of cash flow leading to consumption smoothening. This does not confirm the general perception that the fungibility of funds is a reason for low impact.

\subsection{Agri-Business Advisory Service}

Two of the three MFIs offered additional services like agri-business advice for helping the borrower grow. These services were not complementary but were another product of the MFI. There were no takers for these services as per the admission of MFI staff. As a rule, borrowers either did not know that the company (MFI) had any service to help them or there was clear disinterest amongst those who knew about it. Clients do not want to pay for a service, which does not bring immediate results. Secondly, the credit is given for already running enterprises so the chargeable advisory service was not adding to a skill set. Studies like Augsburg (2008) have found these services to be even loss incurring for the clients. All these reasons together lead to a lack of interest in agribusiness services. That explains the reason for findings in earlier studies that credit plus services are supply-driven and have no positive impact on growth. More importantly, we find that even MFIs are not aggressively promoting these services. One reason could be that these do not bring immediate high returns, as done by the financial services.

\section{Conclusion}

The findings explain why majority studies have found evidence that the impact of microcredit program is just consumption smoothening and not substantial growth in income. This is because MFI credit policies are not designed to create a transformative impact. Cost-cutting and resource optimization- not the focus on the growth of an enterprise, guide the 
credit policy of the MFI. Highly standardized products are offered without taking into account the needs of the clients. MFIs prefer clients with a certain standing and those who have already invested in the productive asset. Secondly, the appraisal is done based on the present repayment capacity and not based on the growth prospects of enterprises. Thirdly, a single product is offered without taking into account the varied enterprise business needs. Fourthly, the loan amount is too small to cater to even the working capital needs of the enterprise. Finally, credit plus programs have remained supply-driven and do not cater to the actual requirements of the clients. Based on these we conclude that the microcredit business model may be good but credit policies of MFIs cater to the profit motive of MFIs and not to genuine business needs of the microenterprises. At the same time, we find that microcredit is a welcome loan. The positive role of microcredit cannot be negated even if it brings about just consumption smoothening. Handling vulnerability is equally important as poverty is dynamic in nature and the slightest reason can push those above the poverty line to below it. Microcredit can address transitory poverty. But assigning the responsibility of poverty reduction to private sector-led financial inclusion is not justified. This study concludes that MFI is a successful vehicle for financial inclusion at the bottom of the pyramid. But the expectation of poverty reduction through micro-credit is based on the wrong premise. The government cannot outsource development and poverty reduction to MFIs.

\section{Reference}

Asian Development Bank (1997), Asian Development Bank Microenterprise Development: Not by Credit Alone, Asian Development Bank, Manila.

Adams, S., \& Bartholomew, T. A. (2010). The impact of microfinance on maize farmers in Nkoranza (Brong Ahafo Region of Ghana). Journal of Management Research, 2(2), I.

Augsburg, B. (2008). Microfinance Plus-Impact of the 'plus' on customers' income in rural India. Maastricht Graduate School of Governance, University Maastricht, the Netherlands.

Banerjee, A., Karlan D., Zinman J. (2014). Six Randomized Evaluations of Microcredit: Introduction and Further Steps, American Economics Journal, (I), I- 32.

Bateman, M., \& Chang, H. J. (2008). Microfinance Illusion: mimeo. University of Juraj Dobrila Pula, Croatia, and University of Cambridge, UK.

Chowdhury, A. (2009). Microfinance as a poverty reduction tool: a critical assessment.

Cohen, M. (2002). Making microfinance more client-led. Journal of International Development, I4(3), 335.

Crépon, B., Devoto, F., Duflo, E., \& Parienté, W. (20I I). Impact of microcredit in rural areas of Morocco: Evidence from a Randomized Evaluation (No. 6659). MIT Working paper.

Dichter, T. (2007). A second look at microfinance. Development Policy Briefing Paper, (I).

Duvendack, M., Palmer-Jones, R., Copestake, J. G., Hooper, L., Loke, Y., \& Rao, N. (20II). What is the evidence of the impact of microfinance on the well-being of poor people?.

Field, E., Pande, R., Papp, J., \& Rigol, N. (2013). Does the classic microfinance model discourage entrepreneurship among the poor? Experimental evidence from India. American Economic Review, I03(6), 2196-2226.

Kuzilwa, J. A. (2005). The role of credit for small business success: A study of the National Entrepreneurship Development Fund in Tanzania. The Journal of Entrepreneurship, I4(2), I3I-I6I.

Meyer, R. L. (2002). The demand for flexible microfinance products: lessons from Bangladesh. Journal of international development, I4(3), 35I-368.

M- CRIL Microfinance Review. (20I4). M- CRIL Microfinance Review 20I4, Risk Regulation and Reward.

Nichter, S., \& Goldmark, L. (2009). Small firm growth in developing countries. World development, 37(9), I453-I464.

Pralahad, C. K. (2004). Fortune at the bottom of the pyramid: Eradicating poverty through profits. Upper Saddle River, NJ: Wharton School Publishing.

Sinha, S. (2007). Efficiency with growth: the emerging face of Indian micro finance. ADB-Finance for the Poor, 8(3).

Yunus, M. (1998). Banker to the Poor. Penguin Books India.

\section{Copyrights}

Copyright for this article is retained by the author(s), with first publication rights granted to the journal. This is an openaccess article distributed under the terms and conditions of the Creative Commons Attribution license (http://creativecommons.org/licenses/by/4.0/). 